\title{
Contribution to the knowledge of the genus Cladonia in Macaronesia
}

\author{
Israel Pérez-Vargas, Cristina González-Montelongo, Consuelo Hernández-Padrón \\ y Pedro Luis Pérez de Paz ${ }^{1}$
}

\begin{abstract}
Pérez-Vargas, I.; González-Montelongo, C; Hernández-Padrón, C. \& Pérez de Paz, P. L. 2015. Contribution to the knowledge of the genus Cladonia in Macaronesia. Bot. Complut. 39: 31-35.

Sixteen species of the genus Cladonia are reported from Macaronesia from the Canary Islands. Three species are new to canarian flora and, two of them new to Macaronesia. The chemical variation of the taxa is reported. A phytogeographic distribution of the taxa with data on their habitat and ecology are presented.
\end{abstract}

Key words: lichen, Canary Islands, biogeography, taxonomy.

Resumen: Pérez-Vargas, I.; González-Montelongo, C; Hernández-Padrón, C. \& Pérez de Paz, P. L. 2015. Contribution to the knowledge of the genus Cladonia in Macaronesia. Bot. Complut. 39: 31-35.

Se citan 16 especies del género Cladonia de la Región Macaronésica de las Islas Canarias. Tres especies son nuevas citas para el archipiélago canario y de ellas dos lo son para la Macaronesia. Se comenta la variación química de los taxones así como su distribución geográfica y datos de su hábitat y ecología.

Palabras clave: liquen, Islas Canarias, biogeografía, taxonomía.

\section{INTRODUCTION}

The genus Cladonia includes more than 450 species worldwide (Litterski \& Ahti 2004, Pino-Bodas et al. 2013b). In the last years, the phylogenetic position, status and delimitation of the family Cladoniaceae and the genus Cladonia have been extensive debated in many works (Stenroos \& DePriest 1998, Wedin et al. 2000, Ahti \& DePriest 2001, Stenroos et al. 2002a,b). Stenroos et al. (2002a) proposed a new classification of the genus in three subdivisions. Within these subdivisions four supergroups and further, seven groups and two subgroups were distinguished. In the Canary Islands the four supergroups (Cladonia, Perviae, Cocciferae and Crustaceae) are represented (Hernández Padrón \& Pérez-Vargas 2010).

Knowledge of species distribution is an integrative tool between systematic and ecology and therefore indispensable for the evaluation of biodiversity; distribution data of species is also essential for estimation of their extinc- tion risk and classification into threat categories (Litterski \& Otte 2002). The genus Cladonia is still insufficiently known in the Canary Islands. There are some data published of this group in dispersed works, most of them without indication of author and locality, and compiled by Hafellner $(1995,1999,2002,2005)$ in his Macaronesian checklist. The only detailed of this genus in the Canaries were due to Etayo \& Burgaz (1997) and Sicilia et al. (2009). The aim of this investigation was extend the previous lichenological knowledge of the genus Cladonia in this area.

\section{MATERIALS AND METHODS}

The morphology of the lichen specimens was examined using a Leica ZOOM 2000 stereomicroscope. Section for anatomical examination were cut by hand and mounted and observed in water. Chemical constituents were identified by thin-layer chromatography (TLC) using standardized procedure and using solvents A, B and C (Elix \& Ernst-Russell 1993, Orange et al. 2001). The material studied is deposited in TFC- Lich and

\footnotetext{
${ }^{1}$ Dpto. Botánica, Ecología y Fisiología Vegetal, Sección de Farmacia, Fac. de Ciencias de la Salud. Universidad de La Laguna, 38201 Tenerife, Canary Islands, Spain. ispeva@ull.es, chely.hernandez@ull.es, pperez@ull.es

Recibido: 7 abril 2015. Aceptado: 23 abril 2015.
} 
some duplicates are in MACB. The species were determined by their morphological and chemical characters.

\section{RESULTS AND DISCUSSION}

Cladonia cervicornis (Ach.) Flot. subsp. cervicornis Jahrb. schles. Ges. vaterl. Kultur 27: 31, 1849.

La Palma: curso del bco. de la Laja Azul, 1200 m, Hernández \& Pérez, November 1999, TFC Lich: 7040; El Riachuelo, 1250 m, Hernández \& Pérez, November, 2001, TFC Lich: 7033.

Chemistry.-Fumarprotocetraric acid.

Habitat and distribution.- On mossy soil. Subcosmopolitan.

Observations. - It was reported from Macaronesia (Azores, Madeira and the Canary Islands) by Tavares (1952). It is a widespread species in the Macaronesian Region, however, it is not common in the Canaries. Outside, it is known from Europe and North America.

Cladonia cyathomorpha Stirt. ex Walt. Watson

J. Bot. 73: 156, 1935.

La Palma: La Cumbrecita, 1280 m, Hernández \& Pérez, November 1999, TFC Lich: 2690.

Chemistry.-Fumarprotocetraric acid.

Habitat and distribution.- On mossy soil. West Europe, S America (Tierra del Fuego).

Observations.- Only reported from the Macaronesian Region by James (2009) and from the Canary Islands by Burgaz \& Ahti (2009), but without any indication of island or locality.

\section{Cladonia fimbriata (L.) Fr.}

Lichenogr. Eur. Ref.: 222, 1831

La Palma: Cabecera del bco Bombas de Agua, 2190 m, Hernández \& Pérez, May 1999, TFC Lich: 7115; Unión bco Roque-Hoyo Verde, 1500 m, Hernández \& Pérez, July 2000, TFC Lich: 7049.

Chemistry.- Fumarprotocetraric acid and occasionally zeorin.

Habitat and distribution.-On mossy soil. Cosmopolitan.

Cladonia firma (Nyl.) Nyl.

Bot. Z., 1861: 352, 1861

La Palma: bco. de Las Verduras de Alfonso, 900 m, Sánchez \& Sicilia, April 2000, TFC Lich: 7044.
Chemistry.-Fumarprotocetraric acid and atranorin.

Habitat and distribution.- On soil. Most frequent in the Mediterranean Region but extends to the Eurosiberian and Macaronesian Region. It is also reported from North America, however, the taxonomic status of the North American samples is somewhat uncertain (Ahti \& Hammer 2002). It is a common species growing on soil on exposed open areas usually mixed with mosses in the Canarian laurel forest.

\section{Cladonia floerkeana (Fr.) Flörke}

De Cladon.: 99, 1828.

Tenerife: Anaga, Cueva del Guanche, February 2014, on Erica arborea, González-Montelongo \& Pérez-Vargas, TFC Lich: 14196g.

Chemistry.-Barbatic and squamatic acids.

Habitat and distribution.- On Erica arborea between mosses. It is not easy to specify its distribution because is easily confused with C. macilenta Hoffm. (Burgaz \& Ahti, 2009).

Observations.- Previously reported from Macaronesia from the Azores (Tavares 1952). New to Canary Islands.

Cladonia foliacea (Huds.) Willd.

Fl. Berol.: 363, 1787.

La Palma: El Riachuelo, 1200 m, Hernández \& Pérez, November 1999, TFC Lich: 2892; El Riachuelo-La Cumbrecita, 1250 m, Hernández \& Pérez, November 2001, TFC Lich: 3896.

Chemistry.-Fumarprotocetraric and usnic acid.

Habitat and distribution. - On mossy soil. Widespread in the Mediterranean Region although reaches the Eurosiberian Region, too.

Observations.-The variation and delimitation of this species towards C. convoluta (Lam.) Anders were discussed by Burgaz et al. (1993). Nevertheless, recent molecular studies would seem to indicate that are conspecific (Pino-Bodas et al. 2010). Cladonia angustiloba Ahti \& Aptroot is a similar species that occurs in similar habitats and it is characterised by the yellow color of the squamules and the very narrow basal squamules, much narrower than in C. foliacea (Ahti \& Aptroot 2009).

\section{Cladonia hammeri s.l.}

La Palma: sendero Cumbrecita-Mirador de los Roques, $1300 \mathrm{~m}$, Pérez-Vargas, April 2004, TFC Lich: 5565, 7028, 7029. 
Chemistry.-Fumarprotocetraric acid.

Habitat and distribution.- Soil. W North America and Iberian Peninsula.

Observations.- This taxon was described from Sonoran Desert Region, North America (Ahti \& Hammer 2002). It is very probably overlooked, include in C. pyxidata s.l. This is the second report from the Macaronesian Region, previously recorded from La Gomera (Sicilia et al. 2009). The identity of the European samples is uncertain and we accept this species in the broad sense, because they differ genetically from the American samples (Pino-Bodas et al. 2013).

Cladonia humilis (With.) J. R. Laundon

Lichenologist 16, 3: 220, 1984.

La Palma: trayecto Los Brecitos-Tenerra, 1000 m, Hernández, Pérez \& Pérez-Vargas, February 2002, TFC Lich: 3969; trayecto Valencia-Bejenado, 1200 m, Hernández, Pérez \& Pérez-Vargas, February 2002, TFC Lich: 4113; alrededores de Los Brecitos, 1075 m, Hernández \& Pérez, May 1999, TFC Lich: 7054; Unión bco Roque-Hoyo Verde, 1500 m, Hernández \& Pérez, July 2000, TFC Lich: 7050.

Chemistry.-Fumarprotocetraric acid and atranorin. litan.

Habitat and distribution.- On mossy soil. Cosmopo-

Observations.- Reported to the Macaronesian Region from Azores by Tavares (1952). In the Canary Islands only known from Tenerife (Gil González et al. 1990) and La Gomera (Sicilia et al. 2009). New to La Palma Island.

Cladonia macrophylla (Schaer.) Stenh.

Lich Suec. Exs., ed. 2: 186, 1865.

La Palma: bco. del Limonero, 1050 m, Muñoz \& Rebolé, March 2001, TFC Lich: 5948.

Chemistry.- Psoromic acid and atranorin.

Habitat.-Soil.

Observations.- It is an artic-alpine species of the northern hemisphere, widely distributed throughout the artic and boreal zone, not known from the Mediterranean region. The southernmost localities are in the Rocky Mountains, Appalachians, China and Portugal (Litterski \& Ahti 2004). New to Macaronesian archipelagos.

Cladonia prolifica Ahti \& S. Hammer Mycotaxon 37: 342, 1990.

La Palma: El Riachuelo-La Cumbrecita, 1250 m, Hernández \& Pérez, November 2001, TFC Lich: 7035, 7116; proximidades de la
Casa de Tenerra, 1050 m, Hernández, Pérez \& Pérez-Vargas, TFC Lich: 3976.

Chemistry.- Fumarprotocetraric acid.

Habitat and distribution.- Soil. North America and

W Europe.

Observations.-This species resembles C. phyllopho$\mathrm{ra}$ Hoffm. very much, but the base is not melanotic and it has no subarachnoid surface structures (Hammer \& Ahti 1990, Burgaz \& Ahti 2009). It would represent another disjunction between North America and Macaronesia and West Mediterranean region (Kärnefelt 1980). Only reported from the Macaronesian region from La Gomera by Sicilia et al. (2009). New to La Palma Island.

\section{Cladonia pseudopityrea Vain.}

Acta Soc. Fauna Flora fenn. 4: 452, 1887.

La Palma: unión Bco Roque-Hoyo Verde, 1500 m, Hernández \& Pérez, July 2000, TFC Lich: 7051; Lomo de Tacote, 1059 m, Muñoz \& Rebolé, January 2001, TFC Lich: 5631.

Chemistry.-Fumarprotocetraric and confumarprotocetraric acids.

Habitat and distribution. - Soil. Mediterranean Region, rarely reaches the Eurosiberian Region.

Observations. - It is a rare and overlooked species very confused with $C$. ramulosa (With.) J. R. Laundon (Ahti \& Puntillo 1995, Burgaz \& Ahti 2009). New to Macaronesian Region.

\section{Cladonia pulvinella s.1.}

La Palma: proximidades de las Casa de Tenerra, $1050 \mathrm{~m}$, Hernández \& Pérez, November 2001, TFC Lich: 3977; Cumbrecita-Mirador de Los Roques, 1300 m, Pérez-Vargas, December 2006, TFC Lich: 7057.

Chemistry._- Fumarprotocetraric acid and atranorin. Habitat and distribution.- Soil, very common. North America, Southern Europe.

Observations.- This species was described from North America (Hammer 1991). It is known from southern Europe, but this species and its allies need comprehensive taxonomic studies in this area (Burgaz et al. 1999). The identity of the European samples is quite uncertain and we accept this species in the broad sense, because they differ genetically from the American samples (Pino-Bodas et al. 2013). 
Cladonia pyxidata (L.) Hoffm.

Deutschl. Flora 2: 121, 1796.

La Palma: El Riachuelo-La Cumbrecita, 1250 m, Hernández \& Pérez, November 2001, TFC Lich: 7034.

Chemistry. - Fumarprotocetraric acid.

Habitat and distribution. Soil. Cosmopolitan.

Observations.- Very polymorphic. The taxonomy of this group is still not clear, specially, with respect to $C$. chlorophaea (Flörke ex Sommerf.) Spreng. and related taxa. A phylogenetic study has shown that $C$. pyxidata and C. pocillum are genetically indistinguishable (Kotelko \& Piercey-Normore 2010). The name was often used in a very wide sense in the past, old records need to be checked in our area.

Cladonia ramulosa (With.) J. R. Laundon

Lichenologist 16(3): 225, 1984.

La Palma: proximidades de la Casa de Tenerra, 1050, Hernández, Pérez \& Pérez-Vargas, TFC Lich: 7030.

Chemistry.-Fumarprotocetraric acid.

Habitat and distribution.- On Pinus trunks. Subcosmopolitan.

Observations.- - It is a very polymorphic taxon, often confused with other Cladonia species in the past. Only known from Macaronesia from two localities in the Canaries from La Palma (Etayo \& Burgaz 1997) and Tenerife (Tavares 1952 as C. pytirea (Flk.) Fr.)

Cladonia rangiformis Hoffm.

Deutschl. Flora 2: 114, 1796.

La Palma: cauce del bco. Las Traves, 1100 m, Hernández \& Pérez, April 2000, TFC Lich: 7056; El Riachuelo-La Cumbrecita, 1250 m, Hernández \& Pérez, TFC Lich: 3919, 3923; Cumbrecita-
Mirador de Los Roques, 1300 m, Pérez-Vargas, December 2006, TFC Lich: 7059 .

Chemistry.-Atranorin and frequently rangiformic acids.

Habitat and distribution.- - On mossy soil. Eurasian region reaches to all Macaronesian Archipelagoes.

Observations.- Although the presence of attached squamules at the podetia are rather rare (James 2009) in our material is very frequent. Cladonia rangiformis Hoffm. var. gracillima which forms round tufts of very delicate, brittle podetia is reported too from Macaronesia (Berger $\&$ Aptroot 2002), but we did not found any samples of this variety among our specimens.

Cladonia subturgida Samp.

Ann. Acad. Polytechn. Porto 13: 106, 1918.

La Palma: trayecto Valencia-Bejenado, 1200 m, Hernández, Pérez \& Pérez-Vargas, February 2002, TFC Lich: 4093; P.N. Caldera de Taburiente, 2150 m, Rebolé, August 1999, TFC Lich: 7047.

Chemistry.-Atranorin and protolichesterinic acid.

Habitat and distribution.- On soil. Iberian Peninsula, Canary Islands.

Observations.- Recently synonimized with C. iberica Burgaz \& Ahti (Pino-Bodas et al. 2012). Only reported from the Macaronesian region from La Gomera (Canary Islands) as C. iberica by Etayo \& Burgaz (1997). New to La Palma Island.

\section{ACKNOWLEDGEMENTS}

The first author is very grateful to Spanish Lichen Society, particularly to A. R. Burgaz to organize a specialization course of the genus Cladonia; L. Fraile-McCord is gratefully acknowledged for linguistic corrections. Partial funding for this research was provided by «Asociación de Antiguos Alumnos y Amigos de la Universidad de La Laguna».

\section{BIBLIOGRAPHY}

Aнті, T. \& AртR0от A. 2009. Two new species of Cladonia from the Azores. Biblioth. Lichenol. 99: 11-17

Ahti, T. \& Puntillo D. 1995. The status of Cladonia pseudopityrea, an overlooked mediterranean lichen. In: F. J. A. Daniels et al. (eds.), Flechten Follmann, Bot. Inst. Univ. Cologne: $155-160$.

Ahti, T. \& Depriest P. 2001. New combinations of Cladina epithets in Cladonia (Ascomycotina: Cladoniaceae). Mycotaxon 78: 499-502.
Ahti, T. \& Hammer, S. 2002. Cladonia. In: T. H. Nash III, B. D. Ryan, C. Gries \& F. Bungartz (Eds.), Lichen Flora of the Great Sonora Desert, 1: 131-158. Lichens Unlimited ASU, Tempe.

Berger, F. \& APTROOT A. 2002. Further contributions to the flora of lichens and lichenicolous fungi of the Azores. Arquipélago 19A: 1-12.

Burgaz, A. R. \& Ahti T. 1994. Contribution to the study of the genera Cladina and Cladonia in Spain. II. Nova Hedwigia 59: 399-440. 
Burgaz, A. R. \& Ahti, T. 2009. Cladoniaceae. Flora Liquenológica Ibérica, 4. Sociedad Española de Liquenología. Madrid. 111 pp.

Burgaz, A. R.; Escudero, A. \& AhTI, T. 1993. Morphometric variation in primary squamules of Cladonia foliacea and C. convoluta. Nova Hedwigia 57: 231-238.

Burgaz, A. R.; Ahti, T. \& Carvalho, P. 1999. Contribution to the study of Cladoniaceae in Portugal. Portugaliae Acta Biol., sér B, Sist. 18: 121-168.

EliX, J. A. \& ERnst-Russell, K. D. 1993. A catalogue of standardized thin layer chromatographic data and biosynthetic relationships for lichen substances. 2nd Edn. Canberra. Australian National University.

Etayo, J. \& Burgaz, A. R. 1997. Contribution to the lichen-forming fungi from the Canary Islands III. The genus Cladonia. Ann. Nat. Hist. Mus. Wien, Ser B Bot. Zool. 99 B: 721-725.

Gil González, M. L.; Hernández-Padrón, C. E. \& Pérez de PAz, P. L. 1990. Catálogo de los líquenes epifíticos y terrícolas del Bosque de Madre del Agua (Agua García, Tenerife, Islas Canarias). Vieraea 19: 95-110.

HAFELLNER, J. 1995. A new checklist of lichens and lichenicolous fungi of insular Laurimacaronesia including a lichenological bibliography for the area. Fritschiana 5: 1-132.

Hafellner, J. 1999. Bemerkenswerte Funde von Flechten und lichenicolen Pilzen auf makaronesischen Inseln. I. In: F. J. A. Daniels et al. (Eds.), Flechten Follmann, Bot. Inst. Univ. Cologne: 428-439.

HAFELLNER, J. 2002. Bemerkenswerte Funde von Flechten und lichenicolen Pilzen auf makaronesischen Inseln II . Herzogia 11: 133-142.

HAFELLNER, J. 2005. Bemerkenswerte Funde von Flechten und lichenicolen Pilzen auf makaronesischen Inseln III. Linzer biol. Beitr. 27(2): 489-505.

Hammer, S. \& Ahti, T. 1990. New and interesting species of Cladonia from California. Mycotaxon 37: 335-348.

Hammer, S. 1991. A preliminary synopsis of the species of Cladonia in California and adjacent Oregon. Mycotaxon 40: 169-197.

Hernández Padrón, C. E. \& Pérez-Vargas, I. 2010. Lichenes, lichenicolous fungi. In: M. Arechavaleta et al. (Coord.) Lista de especies silvestres de Canarias. Hongos, plantas y animales terrestres. 2009. Consejería de Medio Ambiente y Ordenación Territorial. Gobierno de Canarias.

James, P. W. 2009. Cladonia. In: C. W. Smith et al. (Eds.), The Lichens of Great Britain and Ireland: 309-338. British Lichen Society, London.

KÄRNEFELT, I. 1980. Lichens of western North America with disjunctions in Macaronesia and West Mediterranean region. Bot. Not. 133: 569-577.
LitTeRski , B. \& OtTe, V. 2002. Biogeographical research on european species of selected lichen genera. Biblioth. Lichenol. 82: 83-90.

LitTerski, B. \& Ahti, T. 2004. World distribution of selected European Cladonia species. Acta Univ. Ups. Symb. Bot. Ups. 34: 205-236.

Orange, A.; James, P. W. \& White, F. J. 2001. Microchemical methods for the identification of lichens. British Lichen Society, London

Pino-Bodas, R.; Martín, M. P. \& Burgaz, A. R. 2010. Insight into the Cladonia convoluta-C. foliacea (Cladoniacea, Ascomycota) complex and related species, revealed through morphological, biochemical and phylogenetic analyses. Syst. Biodivers. 8: 575-586.

Pino-Bodas, R.; Martín, M. P. \& Burgaz A. R. 2012. Cladonia subturgida and $C$. iberica (Cladoniaceae) form a single, morphologically and chemically polymorphic species. Mycol. Prog. 11: 269-278.

Pino-Bodas, R.; Ahti, T., Stenroos; S.; Martín, M. P. \& BurGAZ, A. R. 2013a. Multilocus approach to species recognition in the Cladonia humilis complex (Cladoniaceae, Ascomycota). Am. J. Bot. 100: 664-678.

Pino-Bodas, R.; Martín, M. P.; Burgaz, A. R. \& Lumbsch, T. 2013b. Species delimitation in Cladonia (Ascomycota): a challenge to the DNA barcoding philosophy. Mol. Ecol. Resour. 13: 1058-1068.

Sicilia, D.; Hernández Padrón, C. \& Burgaz, A. R. 2009. The genus Cladonia in Garajonay National Park, La Gomera, Canary Islands. Cryptogamie, Mycol. 30: 305-316.

Stenroos, S. \& Depriest, P. T. 1998. SSU rDNA phylogeny of Cladoniiform lichens. Am. J. Bot. 85(11): 1548-1559.

Stenroos, S.; Hyvönen, J.; Myllys, L.; Thell, A. \& Ahti, T. 2002a. Phylogeny of the genus Cladonia s. lat. (Cladoniaceae, Ascomycetes) inferred from molecular, morphological, and chemical data. Cladistics 18: 237-278.

Stenroos, S.; Myllys, L.; Thell, A. \& Hyvönen, J. 2002 b. Phylogenetic hypotheses: Cladoniaceae, Stereocaulaceae, Baeomycetaceae, and Icmadophilaceae revisited. Mycol. Prog. 1(3): 267-282.

TAVAres, C. N. 1952. Contribution to the lichen flora of Macaronesia I. Lichens from Madeira. Portugaliae Acta Biol., B, 3(3): 308-391.

Wedin, M.; Döring, H. \& Ekman, S. 2000. Molecular phylogeny of the lichen families Cladoniaceae, Sphaerophoraceae, and Stereocaulaceae (Lecanorales, Ascomycotina). Lichenologist 32(2): 171-187. 